\title{
TP53 mutated AML subclones exhibit engraftment in a humanized bone marrow ossicle mouse model
}

\author{
Gabriel Pabst ${ }^{1} \cdot$ Karin Lind $^{1} \cdot$ Ricarda Graf $^{2} \cdot$ Armin Zebisch $^{1,3}$ (D) $\cdot$ Friedrich Stölzel $^{4} \cdot$ Konstanze Döhner $^{5}$. \\ Ellen Heitzer ${ }^{2}$ (D) Andreas Reinisch ${ }^{1}$ (D) $\cdot$ Heinz Sill $^{1}$ (D)
}

Received: 18 December 2019 / Accepted: 14 January 2020 / Published online: 30 January 2020

(C) The Author(s) 2020

Dear Editor,

Despite extensive efforts to develop novel therapies, the prognosis of patients with acute myeloid leukemia (AML) is still poor. One of the reasons is the genetic heterogeneity of AML with the majority of patients exhibiting distinct mutational subclones and diverse biological characteristics $[1,2]$. TP53 mutated AMLs are frequently resistant to intensive treatments and we recently showed that subclonal TP53 mutations confer an equally devastating prognosis [3]. This observation lead us to hypothesize that TP53 mutated subclones display characteristics of leukemic stem cells (LSCs) thus contributing to relapse or resistant disease. We, therefore, tested LSC properties of these subclones in a recently developed, highly sensitive humanized bone marrow (BM) ossicle xenotransplantation mouse model $[4,5]$.

Patient specimens, experimental methods, and ethical approvals are described in detail in the Supplementary Data. Briefly, BM-derived mesenchymal stromal cells (MSCs) from healthy donors were expanded in vitro and subcutaneously injected into four sites of immunodeficient

Gabriel Pabst, Karin Lind, Andreas Reinisch and Heinz Sill contributed equally to this work.

Electronic supplementary material The online version of this article (https://doi.org/10.1007/s00277-020-03920-y) contains supplementary material, which is available to authorized users.

Andreas Reinisch

a.reinisch@medunigraz.at

Heinz Sill

heinz.sill@medunigraz.at

1 Division of Hematology, Department of Internal Medicine, Medical University of Graz, Auenbruggerplatz 38, 8036 Graz, Austria

2 Institute of Human Genetics, Medical University of Graz, Graz, Austria
$\mathrm{NOD} / \mathrm{SCID} / \gamma^{\text {null }}$ (NSG) mice. These MSCs underwent endochondral ossification leading to the formation of a humanized BM ossicle microenvironment. We transplanted three diagnostic, T cell depleted AML specimens into ossicle-bearing NSG mice either by tail vein or direct intraossicle injection. Two specimens showed subclonal TP53 mutations with a variant allele frequency (VAF) of $<20 \%$, one a clonal TP53 mutation serving as control (Supplementary Table 1). Mice were sacrificed 16 18 weeks post transplantation and humanized ossicles as well as mouse BM were analyzed for the engraftment of human leukemia. Leukemia engraftment was analyzed by multicolor flow cytometry, and different engrafted cell populations were sorted based on the expression of hCD45, hCD33 and hCD19 (Supplementary Fig. 1). gDNA of sorted cells was analyzed for patient-specific TP53 and cooperating mutations using high-resolution mutation profiling allowing for the detection of mutations with a VAF of $<0.1 \%$ [6].

All three AML specimens showed engraftment in humanized ossicles as well as mouse BM. However, human
3 Otto Loewi Research Center for Vascular Biology, Immunology and Inflammation, Division of Pharmacology, Medical University of Graz, Graz, Austria

4 Department of Internal Medicine I, University Hospital Carl Gustav Carus, Dresden University of Technology Dresden, Dresden, Germany

5 Department of Internal Medicine III, University Hospital of Ulm, Ulm, Germany 
Fig. 1 Engraftment of TP53 mutated AML specimens in a humanized bone marrow ossicle mouse model. a, Median human engraftment of AML specimens following tail vein injection in humanized bone marrow ossicles and mouse bone marrow of three mice 16 weeks post transplantation. b,c, Engraftment of two AML specimens with subclonal TP53 mutations. The left panels depict human hematopoietic cells being hCD45+ and HLA-ABC+ and sorted into CD33+ myeloid and CD19+ B-lymphoid cells. The right panels depict variant allele frequencies (VAFs) of the particular TP53 and cooperating mutations in the respective compartments. Error bars denote 95\% confidence intervals.

Abbreviation: $\mathrm{BM}$, bone marrow a

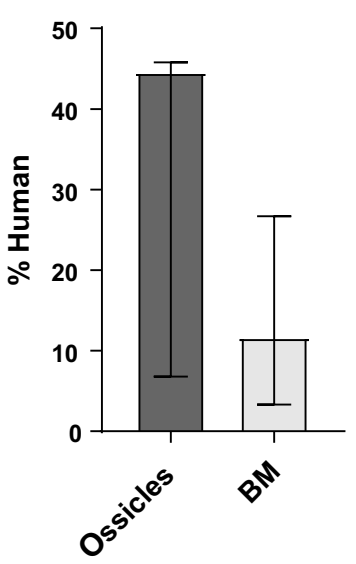

b
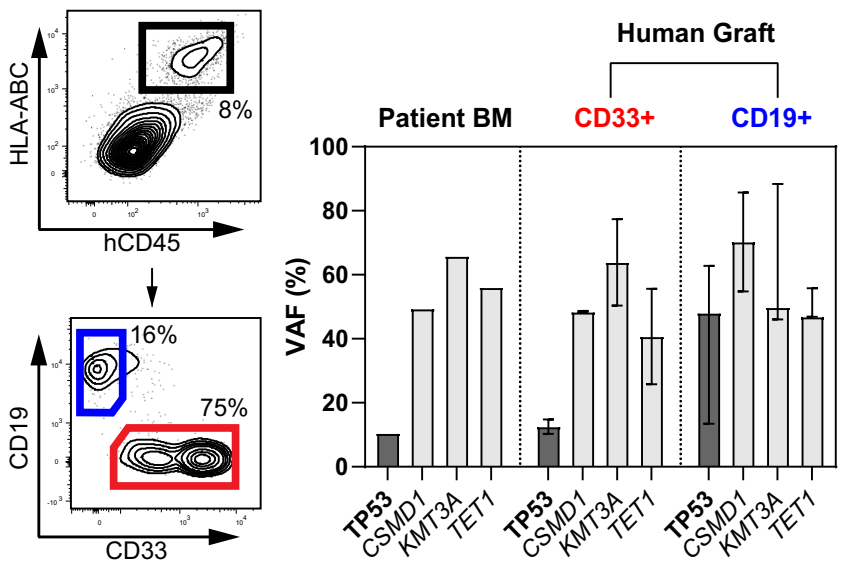

C
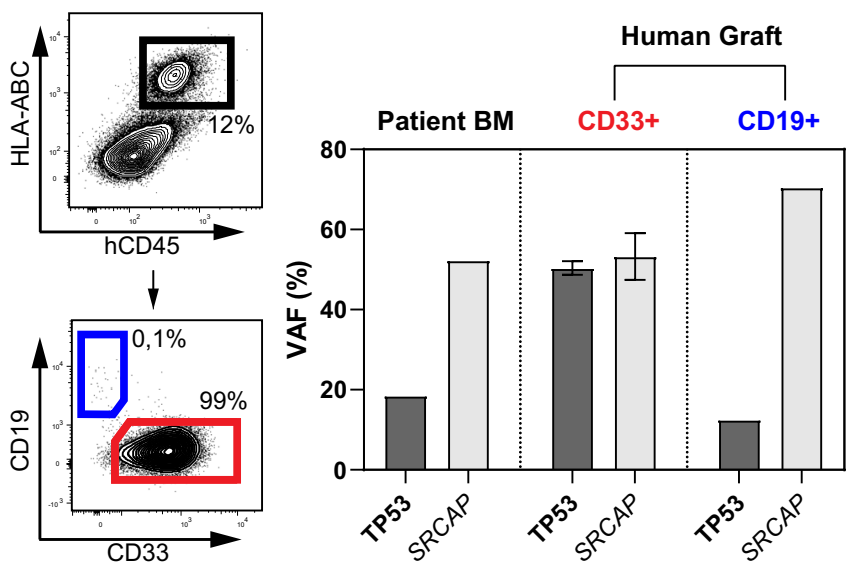

cells preferentially engrafted in the humanized ossicle microenvironment (Fig. 1a, Supplementary Fig. 2). For both AML samples with subclonal TP53 mutations, CD33+ leukemic cells constituted the predominant cell population within the graft. Interestingly, differentiation into CD19+ B-lymphoid cells was also observed and the subclonal TP53 mutations could be detected in both, the engrafted myeloid and lymphoid compartments (Figs. 1b, c; Supplementary Figs. 3,4; Supplementary Tables 2,3). These data indicate that subclones with TP53 mutations reveal characteristics of LSCs and pre-leukemic hematopoietic stem cells (pHSCs) being in line with our previous report on clonal TP53 mutations in AML [7]. Stem cell features may contribute to the fact that AML patients with subclonal TP53 mutations do also face an adverse prognosis since LSCs and pHSCs are considered less vulnerable to cytotoxic therapy ultimately giving rise to relapsed or resistant disease [8]. Similarly, expansion of clones with TP53 aberrations was also shown in murine models exposed to genotoxic stress $[9,10]$. Finally, our data re-emphasize the usefulness of the humanized BM ossicle mouse model, particularly for the engraftment of small myeloid clones.
Acknowledgements We would like to thank Prof. Torsten Haferlach, Munich Leukemia Laboratory, for providing control DNA.

Funding information This work was supported by grants from the Austrian Science Fund (number P31430 to HS and P32783 to AR). A.R. was also supported by the Austrian Society of Internal Medicine (Joseph Skoda Fellowship), the Austrian Society of Hematology and Oncology (Clinical Research Grant) and MEFOgraz.

\section{Compliance with ethical standards}

Conflict of interest The authors declare that they have no conflict of interest.

Open Access This article is licensed under a Creative Commons Attribution 4.0 International License, which permits use, sharing, adaptation, distribution and reproduction in any medium or format, as long as you give appropriate credit to the original author(s) and the source, provide a link to the Creative Commons licence, and indicate if changes were made. The images or other third party material in this article are included in the article's Creative Commons licence, unless indicated otherwise in a credit line to the material. If material is not included in the article's Creative Commons licence and your intended use is not permitted by statutory regulation or exceeds the permitted use, you will need to obtain permission directly from the copyright holder. To view a copy of this licence, visit http://creativecommons.org/licenses/by/4.0/. 


\section{References}

1. Welch JS, Ley TJ, Link DC, Miller CA, Larson DE, Koboldt DC, Wartman LD, Lamprecht TL, Liu F, Xia J, Kandoth C, Fulton RS, McLellan MD, Dooling DJ, Wallis JW, Chen K, Harris CC, Schmidt HK, Kalicki-Veizer JM, Lu C, Zhang Q, Lin L, O'Laughlin MD, McMichael JF, Delehaunty KD, Fulton LA, Magrini VJ, McGrath SD, Demeter RT, Vickery TL, Hundal J, Cook LL, Swift GW, Reed JP, Alldredge PA, Wylie TN, Walker JR, Watson MA, Heath SE, Shannon WD, Varghese N, Nagarajan R, Payton JE, Baty JD, Kulkarni S, Klco JM, Tomasson MH, Westervelt P, Walter MJ, Graubert TA, DiPersio JF, Ding L, Mardis ER, Wilson RK (2012) The origin and evolution of mutations in acute myeloid leukemia. Cell 150(2):264-278

2. Klco JM, Spencer DH, Miller CA, Griffith M, Lamprecht TL, O'Laughlin M, Fronick C, Magrini V, Demeter RT, Fulton RS, Eades WC, Link DC, Graubert TA, Walter MJ, Mardis ER, Dipersio JF, Wilson RK, Ley TJ (2014) Functional heterogeneity of genetically defined subclones in acute myeloid leukemia. Cancer Cell 25(3):379-392

3. Prochazka KT, Pregartner G, Rucker FG, Heitzer E, Pabst G, Wolfler A, Zebisch A, Berghold A, Dohner K, Sill H (2019) Clinical implications of subclonal TP53 mutations in acute myeloid leukemia. Haematologica 104(3):516-523

4. Reinisch A, Thomas D, Corces MR, Zhang X, Gratzinger D, Hong WJ, Schallmoser K, Strunk D, Majeti R (2016) A humanized bone marrow ossicle xenotransplantation model enables improved engraftment of healthy and leukemic human hematopoietic cells. Nat Med 22(7):812-821
5. Reinisch A, Hernandez DC, Schallmoser K, Majeti R (2017) Generation and use of a humanized bone-marrow-ossicle niche for hematopoietic xenotransplantation into mice. Nat Protoc 12(10):2169-2188

6. Stahlberg A, Krzyzanowski PM, Egyud M, Filges S, Stein L, Godfrey TE (2017) Simple multiplexed PCR-based barcoding of DNA for ultrasensitive mutation detection by next-generation sequencing. Nat Protoc 12(4):664-682

7. Lal R, Lind K, Heitzer E, Ulz P, Aubell K, Kashofer K, Middeke JM, Thiede C, Schulz E, Rosenberger A, Hofer S, Feilhauer B, Rinner B, Svendova V, Schimek MG, Rucker FG, Hoefler G, Dohner K, Zebisch A, Wolfler A, Sill H (2017) Somatic TP53 mutations characterize preleukemic stem cells in acute myeloid leukemia. Blood 129(18):2587-2591

8. Reinisch A, Chan SM, Thomas D, Majeti R (2015) Biology and clinical relevance of acute myeloid leukemia stem cells. Semin Hematol 52(3):150-164

9. Wong TN, Ramsingh G, Young AL, Miller CA, Touma W, Welch JS, Lamprecht TL, Shen D, Hundal J, Fulton RS, Heath S, Baty JD, Klco JM, Ding L, Mardis ER, Westervelt P, DiPersio JF, Walter MJ, Graubert TA, Ley TJ, Druley TE, Link DC, Wilson RK (2015) Role of TP53 mutations in the origin and evolution of therapy-related acute myeloid leukaemia. Nature 518(7540):552-555

10. Chen S, Gao R, Yao C, Kobayashi M, Liu SZ, Yoder MC, Broxmeyer H, Kapur R, Boswell HS, Mayo LD, Liu Y (2018) Genotoxic stresses promote clonal expansion of hematopoietic stem cells expressing mutant p53. Leukemia 32(3):850-854

Publisher's note Springer Nature remains neutral with regard to jurisdictional claims in published maps and institutional affiliations. 